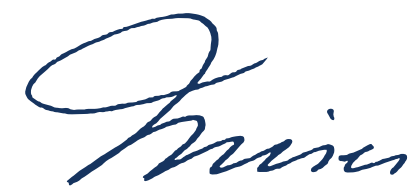

www.misesjournal.org.br

MISES: Interdisciplinary Journal of Philosophy Law and Economics

São Paulo, 2019; 7(3) Set-Dez

e-ISSN 2594-9187

\title{
The first modern economist
}

ESSAY

ON

ECONOMIC

THEORY

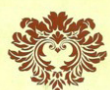

AN ENGLISH TRANSLATION

OF RICHARD CANTILLON

ESSAI SUR LA NATURE

RANSLATED BY CHANTAL SAUCIE

AMNLATED BY CHANTAL SAUCI
EDITE BY MARK THORNTON

\section{Kristoffer Mousten Hansen}

University of Angers, Angers, France

CANTILLON, Richard. An Essay on Economic Theory. Edited by Mark Thornton. Translated by Chantal Saucier. Auburn: Ludwig von Mises Institute, 2010. 252p.

Can anything be learned from reading the works of long-dead economists? Or is that only of interest to historians of economic thought? If science is ever progressing, always adding new truths to what came before and eliminating errors, it would seem that the answer will be no. However, the history of economics is emphatically not like that: time and again, new errors have developed and old fallacies have again risen to a position of orthodoxy. Modern economists may feel convinced of the superiority of their own views, whether they are Neoclassical, Keynesian, Austrian, or of some other school. Yet even should we accept the works of Mises and Rothbard as the correct expression of the principles of our science, this does not mean that we can ignore earlier thinkers. For not only may the precursors of the current masters have emphasized different points, making their books a shortcut to a fuller understanding of economics, they may also have preserved a clearer conception of some ideas that have since been neglected or forgotten.

An Essay on Economic Theory by Richard Cantillon is just such a book (CANTILLON, 2010). It is remarkable, not only for its place in the history of economics, but also for the extend to which it is still fruitful to study it in depth. It is perhaps the first treatise devoted to pure economics, as opposed to mercantilistic pamphlets advocating policies or scholastic treatises on ethics that only incidentally touch on economic issues. To this day, it is worth studying for the student of location theory, entrepreneurship, and monetary economics, as well as

* Kristoffer Mousten Hansen is currently working on his PhD dissertation on monetary interventionism and agriculture at the University of Angers in France. He has thrice been a Summer Fellow at the Ludwig von Mises Institute.

E-mail: kristoffer.moustenhansen@etud.univ-angers.fr 
being an early case study in the verbal-logical or causal-realist method in economics. In the following, we will first briefly examine Cantillon's place in the history of economic thought, before moving on to considering his contributions to these various fields.

\section{Cantillon in the history of economic thought}

Richard Cantillon was out of an old Irish family who had been dispossessed of their ancestral estate during the 1650s during the Cromwellian takeover of Ireland, and most of the family left Ireland after the Glorious Revolution in 1688. The young Richard - we do not know his exact year of birth, but he was probably born in the decade 1680-90 - became a French citizen sometime before 1710, and was first employed by the English paymastergeneral, James Brydges (later $1^{\text {st }}$ Duke of Chandos) before going into business as a banker after the War of Spanish Succession, initially in partnership with his cousin, also named Richard Cantillon. In the years 1719-20 Cantillon made a fortune on the bubbles in Paris London and Amsterdam, successfully speculating in stock, options and foreign exchange. Unfortunately, Cantillon became embroiled in lawsuits throughout the 1720s arising from these transactions, and was even thrown in prison twice. He died in London, where he had made his home, in 1734 , murdered by his former cook who subsequently burned the house to the ground to cover up his crime. His biographer Murphy speculates that Cantillon's murder may have been a cover-up, however: with no end in sight to his lawsuits, Cantillon may have staged his murder, escaping to South America with a large sum of money (MURPHY, 1986).

The Essay was probably written in 1730 but was not published until 1755 . Before that, it circulated widely among intellectuals and professionals, although it is impossible to say how widely due to the nature of the circumstances. It is too much to call Cantillon the father of economics (EVIN, 2013), but his work has, however, always been recognized as a major landmark in the history of economic thought: Schumpeter saw Cantillon as one of the first econometricians (SCHUMPETER, 1954, p. 219-223), a judgment it is hard to sustain: it is based on overvaluing the importance of the supplement to the Essay now lost, if indeed it were ever known to anybody but Cantillon. Ekelund and Hébert come closer to the truth when they describe him as having a Newtonian cast of mind (EKELUND; HÉBERT, 1990, p. 77), although 'Newtonian' risks conjuring up a too mechanical view of the market economy - and Cantillon's was, as we shall see, anything but that.

\section{The Essay on Economic Theory}

One is immediately struck by the scientific tone of the Essay from the get-go. Cantillon begins with definitions: land is the matter from which all wealth is drawn, man's labor provides the form for its production, and wealth itself 'is nothing but the food, conveniences, and pleasures of life' (CANTILLON, 2010, p. 21). The form-matter terminology is redolent of scholastic philosophy, and the classification of land and labor as the original factors hints at William Petty, who called land the mother and labor the father of wealth. However, Cantillon is very much his own man: there are no further allusions to scholasticism, except for his caustic remarks on the casuists and their treatment of usury (CANTILLON, 2010, p. 173-174), 
and the only part of the Essay that shows any influence from Petty is the discussion on the par between land and labor.

The book is divided into three parts, each part building organically on what came before. The first part lays out the basic principles of economics, of production, distribution and consumption, part 2 deals with money and interest rates, while the last part deals with international exchange and banking. Rather than go through each part slavishly, however, we will draw out what are some of the most important contributions Cantillon makes.

\section{Location theory}

One area where Cantillon was the pioneer is in the area of economic geography and spatial economics. While von Thünen is usually seen as the originator of this branch of economics ( $\mathrm{VON}$ THÜNEN, 1966), Cantillon was there before him. Not only is ownership of land important to Cantillon, so is the distribution of people: the workers have to live close to the land they have to work, after all, and it is therefore natural that land that requires a lot of workers - more intensive farming - naturally leads to a denser population, while extensive farming naturally leads to a more dispersed population. From the level of the agricultural workers, Cantillon goes on to explain the formation of towns due to economic factors: merchants have to buy the farmers' products and sell them supplies, and the costs of going from village to village and homestead to homestead to do this mean that it is simpler to do this in a centrally located village, which then grows to provide the products and services needed by the inhabitants of the surrounding countryside. Somewhat surprisingly, perhaps, Cantillon describes cities as simply places of consumption: cities grow because landowners decide to make their home in them, and they are focused on supplying the landowners' needs. The ultimate center of consumption is the capital city, as this is where the king lives as well as the major landowners. In this model of the economy, we can clearly see how rents from land will flow to towns and cities, and the products from the cities will either be consumed there or flow in the other direction. This model is of importance in understanding Cantillon's later discussion of money and international (really interlocal) exchange.

The perhaps weakest part of Cantillon's theory is his attempt to solve the problem of the par between land and labor. This had first been formulated by Petty: what is the par between the two that makes it possible to calculate costs with varying inputs of land and labor? Cantillon's answer is to reduce labor to land: the value of labor is the amount of land it takes to maintain (and reproduce) the laborer in question. While this is more sophisticated than it sounds, it is clearly wrong, even on Cantillon's own terms. For while it is true that land is needed to maintain the laborer, land cannot do so on its own. Remember, land is only the matter of wealth, labor imparts its form, which clearly indicates that land and labor is necessary to maintain labor. In other words, any attempt to solve the problem of the par will result in an infinite regress, as the laborers who work the land that maintain the first laborer will themselves have to be maintained by other laborers and so on ad infinitum. This problem, however, is not central to the Essay, so the failure to recognize the futility of searching for the par does not invalidate the rest of Cantillon's work. 


\section{Cantillon on entrepreneurship}

It is when it comes to discussing the entrepreneur that Cantillon sounds surprisingly modern. Whereas laborers earn fixed wages proportionate to their skill and the risk of their trade, entrepreneurs are not guaranteed any income. The farmer is Cantillon's prime example of an entrepreneur: he pays a fixed sum to the landowner, but he has no assurance of making a future profit. Other entrepreneurs eventually pay the farmer a price for his product, but they in turn are not assured any future profit (CANTILLON, 2010, p. 73-74). What characterizes the entrepreneurs is that they are subject to uncertainty: the other classes in society - landowners and hired laborers - have fixed rents and wages, but the entrepreneurs are never sure what their income will be. Profit and loss are the regulating forces of the economy: more entrepreneurs join trades where profits are to be made, and in those trades where losses are made the least patronized entrepreneurs are driven to bankruptcy.

Cantillon has thus clearly formulated a theory of entrepreneurship that focuses on acting under uncertainty. There is even in embryo some idea of the difference between risk and uncertainty: laborers are rewarded in part due to the risks associated with their occupation, while the entrepreneur earns a profit if he succeeds in selling his product in the inherently uncertain future. All this clearly hints at theories developed more fully by Frank Knight (risk vs. uncertainty), Mises (uncertainty and entrepreneurship), and Foss and Klein (using assets in the present with a view to profit in an uncertain future). What's more, the entrepreneur is central to the functioning of the economy in Cantillon's view. It is the entrepreneurs who, responding to expected profit and loss, direct the economy and guide production toward what consumers demand. His is not a static conception of the economy, far from it: it is always changing as entrepreneurs continue to adapt and as demand continues to change.

This is not to say that the theory of entrepreneurship is fully developed in Cantillon's work. He conceives of laborers as a non-entrepreneurial class, which makes sense, since they work on fixed and therefore known wages. It is not clear how he views the landowners: given that they are the asset owners par excellence in his model of the economy, one would assume that some degree of uncertainty attaches to their position; but this is not spelled out by Cantillon - on the contrary, one at times gets the impression from his account that the landowners too enjoy a very secure position. Nevertheless, Cantillon's description of entrepreneurs as the guiding force of the market process is still very much worth studying.

\section{Monetary theory}

In the area of money, too, Cantillon can still be read with profit. In describing monetary matters, Cantillon combines his experience as a banker with keen theoretical insights. His theory of what money is is not in itself new: his description of the characteristics that made gold and silver suitable as money are the usual ones from Aristotle onward (CANTILLON, 2010, p. 109).

It is when it comes to the production of money that Cantillon sets himself apart. He realizes, first of all, that money is a good produced like all others. That is, in his terms, that the market price and the cost of money in terms of the labor and land that went into producing 
it determine its supply: if the price is above the cost, more resources will be spent in the production of money and its supply will increase: if the price is below the cost, land and labor will not be rewarded in the production of money, and fewer laborers will be employed here, leading to a lower supply. This is not all: Cantillon also describes the non-neutrality of money. It is not indifferent how and where new money enters the economy. He agrees with the cruder quantity theory of money as expressed by John Locke that an increase in the supply of money will lead to higher prices, but chastises Locke for only observing the effect and not explaining the causal process that leads to this outcome (CANTILLON, 2010, p. 147-148).

Here is where Cantillon first describes the process that has since come to bear his name, the so-called Cantillon effects: when new money first enters the economy, real resources are redistributed to those who receive the new money first from those who receive it last or not at all. The mine owners - assuming the new money take the form of additional precious metals - increase their consumption, leading entrepreneurs to invest more in producing those goods favored by the first spenders, and leading to these entrepreneurs and their employees also benefiting from the new money in their own expenditure. Those who lose out in this process are the people on fixed income, first of all landowners during the term of their leases and the classes dependent on them.

Cantillon's understanding of the effects of changes in the money supply goes further: the interest rate is usually set by the proportion between lenders and borrowers - and is thus not in itself a monetary phenomenon - but inflows of new money can affect it in opposing directions: if the new money is spent in consumption, entrepreneurs will expand their business to accommodate the extra demand, and they will borrow money to do this. This will push up the interest rate, as the amount of capital offered by lenders has not increased. On the other hand, if the lenders receive the new money first it will have the opposite effect: more money will be offered on the loan market, and the rate of interest will fall as a result. We have here a very sophisticated understanding of the effects of money flows, even if Cantillon's understanding of what money is has not progressed substantially from his predecessors.

When it comes to international money flows, Cantillon displays the same acute insight. The price-specie flow mechanism whose elaboration is generally attributed to Hume (1987) is described in detail by Cantillon. When one country increases the amount of money in circulation, by whatever means, two things will happen to reverse this situation: domestic prices will increase, reducing exports; and imports will increase as the new money is spent at least partially on foreign goods. In this way, market forces determine the distribution of money among the different nations, despite the intentions and policies of mercantilists (CANTILLON, 2010, p. 203-207).

\section{Conclusion}

These are just some of the reasons that Cantillon's Essay is a timeless classic. There are, for instance, more nuggets of insight in his monetary theory than what has been described here, and his description of the conduct of international - really, interlocal - exchange is to this day a good introduction to international economics. More could also be said about his 
wage theory, where he anticipates Adam Smith's emphasis on compensating differentials, and Cantillon's analysis of banking too is still very much worth reading.

More fundamentally, the Essay shows the importance of good method. For while Cantillon did not write a tract on methodology, it is clear, contra Schumpeter, that Cantillon's approach was systematical verbal-logical analysis of causal processes starting from a few basic principles and assumptions. His statistical supplement was clearly only for illustrative purposes and to elucidate the chimerical problem of the par (notably, all reference to it disappears in parts 2 and 3 of the Essay). The reason for Cantillon's brilliance must clearly be attributed to this approach. Logical analysis and a good grasp of basic principles, in the $18^{\text {th }}$ as well as the $21^{\text {st }}$ century, is the sine qua non of good economic theory.

\section{References}

CANTILLON, Richard. An Essay on Economic Theory. Edited by Mark Thornton. Translated by Chantal Saucier. Auburn: Ludwig von Mises Institute, 2010.

EKELUND, Robert B.; HÉBERT, F. A History of Economic Theory and Method. New York: McGraw-Hill, 1990.

HUME, David. Of the Balance of Trade. In: MILLER, Eugene (ed.). Essays, Moral, Political, and Literary. Indianapolis: LibertyClassics, 1987.

MURPHY, Antoin E. Richard Cantillon, Entrepreneur and Economist. New York: Clarendon Press; Oxford University Press, 1986.

NEVIN, Séamus. Richard Cantillon - the Father of Economics. History Ireland, v. 21, n. 2, p. 20-23, 2013.

SCHUMPETER, Joseph A. History of Economic Analysis. New York: Oxford University Press, 1954.

THÜNEN, Johan Heinrich von. The Isolated State. Oxford: Pergamon Press, 1966.

RECEIVED DATE: SET 102019

ACCEPTED DATE: SET 242019 